\title{
Effect of the self-assembled gel network formed from a low molecular mass organogelator on the electron kinetics in quasi-solid-state dye-sensitized solar cells
}

\author{
Lu Wang ${ }^{1,2}$, Zhipeng Huo ${ }^{1 *}$, Li Tao ${ }^{3 *}$, Jun Zhu ${ }^{1}$, Shuanghong Chen ${ }^{1}, \mathrm{Xu} \mathrm{Pan}^{1}$ and Songyuan Dai ${ }^{1,4^{*}}$
}

\begin{abstract}
A low molecular mass organogelator (LMOG), $N, N^{\prime}$-1,5-pentanediylbis-dodecanamide, was applied to quasi-solid-state dye-sensitized solar cells (QS-DSSCs). The crosslinked gel network was self-assemblied by the LOMG in the liquid electrolyte, and the in situ assembly process of gelator can be obtained by the polarized optical microscopy (POM). On one hand, the network hinders the diffusion of redox species and accelerates the electron recombination at the interface of the $\mathrm{TiO}_{2}$ photoanode/electrolyte. On the other hand, $\mathrm{Li}^{+}$can interact with the amide carbonyl groups of the gelators and the adsorption of $\mathrm{Li}^{+}$onto the $\mathrm{TiO}_{2}$ surface decreases, leading to a negative shift of the $\mathrm{TiO}_{2}$ conduction band edge, accelerated electron transport and decreased electron injection efficiency $\left(\eta_{\text {inj }}\right)$ of QS-DSSC. As a result, the incidental photon-to-electron conversion efficiency (IPCE), the short circuit photocurrent density $\left(J_{s c}\right)$ and the open circuit voltage $\left(V_{o c}\right)$ of the QS-DSSC are decreased compared with those of the liquid electrolyte based DSSC (L-DSSC), which indicates that the electron recombination plays a great role in the photovoltaic performances of DSSC. Remarkably, the QS-DSSC exhibits excellent thermal and light-soaking stabilities during accelerated aging tests for $1000 \mathrm{~h}$, which is attributed to a great intrinsic stability of the gel electrolyte with a high gel to solution transition temperature $\left(T_{\text {gel }}=\right.$ $\left.108^{\circ} \mathrm{C}\right)$.
\end{abstract}

Keywords: dye-sensitized solar cells, quasi-solid-state, low molecular mass organogelator, electron kinetics, stability

\section{INTRODUCTION}

Since significant breakthroughs in 1991, dye-sensitized solar cells (DSSCs) have entered public view and garnered more and more research attention over the following 20 years $[1,2]$. DSSCs are composed of mesoporous nanocrystalline $\mathrm{TiO}_{2}$ thin layers modified with photosensitizing dyes as working electrodes, redox electrolytes and counter electrodes, which have been regarded as a promising candidate for next generation solar energy conversion technology, thanks to potentially low cost, shorter energy consumption, low toxicity of the constituent elements, simple fabrication process and comparatively high power conversion efficiency [3-5]. Each part of the device heavily influences the cost and efficiency of DSSCs, and the redox electrolytes in DSSCs function as the medium to transfer electrons from the counter electrode to the oxidized dye. High efficiencies have been achieved by using liquid electrolytes $[3,6]$. In the case of liquid electrolytes based DSSCs (L-DSSCs), sealing problems and long-term durability substantially hinder the practical application of DSSCs. Therefore, many efforts have been directed toward alternatives to liquid electrolytes, including solid-state electrolytes [7-9] and quasi-solid-state electrolytes [10-12]. However, derivative problems of solid-state electrolytes such as contact between hole transporting materials and the nanoporous semiconductor films remain to be solved $[13,14]$. Therefore, quasi-solid-state electrolytes which can be prepared by solidifying the liquid electrolytes using low molecular mass organogelators (LMOGs) $[15,16]$, polymer gelators $[17,18]$ and nanoparticles $[19,20]$, have

\footnotetext{
${ }^{1}$ Key Laboratory of Novel Thin Film Solar Cells, Institute of Applied Technology, Hefei Institutes of Physical Science, Chinese Academy of Sciences, Hefei 230031, China

${ }^{2}$ University of Science and Technology of China, Hefei 230026, China

${ }^{3}$ Hubei Collaborative Innovation Center for Advanced Organic Chemical Materials, Faculty of Physics and Electronic Science, Hubei University, Wuhan 430062, China

${ }^{4}$ Beijing Key Laboratory of Novel Thin Film Solar Cells, School of Renewable Energy, North China Electric Power University, Beijing 102206, China

*Corresponding authors (emails: zhipenghuo@163.com (Huo Z); sydai@ncepu.edu.cn (Dai S); taoli1107@126.com (Tao L))
} 
attracted much attention for their good properties (e.g., good performance and long stability). Remarkably, the gel electrolytes formed from the LMOGs exhibit three dimensional networks and possess higher ionic conductivity, good pore filling and penetration of the mesoporous $\mathrm{TiO}_{2}$ film [21,22]. Importantly, the devices assembled by LMOGs exhibit good long-term stability because of a high gel to solution transition temperature of LMOGs [23,24].

In this work, $N, N^{\prime}-1,5$-pentanediylbis-dodecanamide as a LMOG was introduced into quasi-solid-state DSSC (QSDSSC) and a novel gel electrolyte was fabricated with the crosslinking gel network by self-assembly. The effects of the network on the charge transport mechanism of this gel electrolyte, kinetic processes of electron transport and recombination, as well as photovoltaic performance and stabilities of the corresponding QS-DSSCs were investigated in detail. In addition, the gel electrolyte possesses a high gel to solution transition temperature $\left(T_{\text {gel }}=108^{\circ} \mathrm{C}\right)$, which is positive to increase the stabilities of QS-DSSC. This work is important and necessary to further understand the detailed mechanism of the influence of LOMG on the QS-DSSCs performances.

\section{EXPERIMENTAL SECTION}

\section{Preparation of the electrolytes}

$N, N^{\prime}$-1,5-pentanediylbis-dodecanamide and 1,2-dimethyl3-propylimidazolium iodide (DMPII) were synthesized according to the previous reported methods $[25,26]$. The liquid electrolyte for DSSCs consisted of $0.1 \mathrm{~mol} \mathrm{~L}^{-1}$ anhydrous lithium iodide (LiI: $99 \%$, Aldrich), $0.1 \mathrm{~mol} \mathrm{~L}^{-1}$ iodine $\left(\mathrm{I}_{2}: 99 \%\right.$, Aldrich), $1 \mathrm{~mol} \mathrm{\textrm {L } ^ { - 1 }}$ DMPII and 0.5 mol L ${ }^{-1} \mathrm{~N}$-methylbenzimidazole (NMBI: 99\%, Aldrich) in 3-methoxypropionitrile (MePN: 99\%, Fluka). In addition, the gel electrolyte containing $6 \mathrm{wt} . \%$ ( $v s$. liquid electrolyte) gelator and liquid electrolyte was heated to $120^{\circ} \mathrm{C}$ under stirring until the gelators melted. After the solution cooled down to room temperature, the gel electrolyte was formed.

\section{Assembly of dye-sensitized solar cells}

Firstly, the $\mathrm{TiO}_{2}$ nanocrystalline layers were created prior to screen-printing on the fluorine doped tin oxide (FTO) glass (TEC-8, LOF) to overcome the weak connectivity between $\mathrm{TiO}_{2}$ sub-microspheres and the FTO glasses. Then, the $\mathrm{TiO}_{2}$ sub-microspheres were screen-printed onto the $\mathrm{TiO}_{2}$ nanocrystalline layers and the films were sintered in air at $450^{\circ} \mathrm{C}$ for $30 \mathrm{~min}$, then cooled to about $120^{\circ} \mathrm{C}$ for next step. The thicknesses of the films were measured using a profilometer (XP-2, AMBIOS Technology, Inc., USA) and the average thickness of the films was about $11 \mu \mathrm{m}$. The nanoporous $\mathrm{TiO}_{2}$ photoelectrodes were immersed in an ethanol solution of $0.5 \mathrm{mmol} \mathrm{L}^{-1}$ cis-dithiocyanate- $\mathrm{N}, \mathrm{N}$-bis(4-carboxylate-4-tetrabutylammoniumcarboxylate-2,2-bipyridine)ruthenium(II) (N719 dye) for $14 \mathrm{~h}$, and the platinized counter electrodes were obtained by spraying $\mathrm{H}_{2} \mathrm{PtCl}_{6}$ solution to the FTO glasses followed by heating at $450^{\circ} \mathrm{C}$ for $20 \mathrm{~min}$. The sensitized $\mathrm{TiO}_{2}$ photoelectrodes were washed with ethanol and dried in air and were assembled by the platinized counter electrodes with $60 \mu \mathrm{m}$ thermal adhesive films (Surlyn 1702, Dupont, USA) under heating and pressure. The liquid electrolyte was injected into the internal space between two electrodes through the hole on the counter electrode, which was later sealed by a cover glass and thermal adhesive films. Finally, the conventional L-DSSCs were obtained. The gel electrolyte was heated to $120^{\circ} \mathrm{C}$ in air under stirring until the gels transformed into liquid state completely. Then, the hot solution of gel electrolytes were respectively injected into the internal spaces between two electrodes through the holes on the counter electrodes, and the gel electrolyte based cells were sealed by a cover glass and thermal adhesive films. After cooling to room temperature, the gel electrolyte based DSSCs (QS-DSSC) were formed.

\section{Materials characterizations}

To research the dynamic process of gel frameworks formation, the polarized optical microscopy was used. The samples were made by dropping the hot solution (gel: 6 wt.\% gelator in MePN) onto the glass slide and protecting with cover slip. The sample was heated to $120^{\circ} \mathrm{C}$ at a rate of $10^{\circ} \mathrm{C} \mathrm{min}^{-1}$ and the micrographs were obtained during cooling between crossed polarizers using a microscope (DM2500P, Leica, Germany) equipped with a hotstage (LTSE-420, Linkam, UK) and a camera (Micropublisher 5.0 RTV, Qimaging, Canada) at a rate of $1^{\circ} \mathrm{C} \mathrm{min}^{-1}$. In addition, the $T_{\text {gel }}$ of the gel electrolyte was determined by differential scanning calorimeter (DSC-Q2000, TA, USA). Approximately 5-7 $\mathrm{mg}$ of the sample was weighed, sealed in an aluminum pans and heated at a rate of $10^{\circ} \mathrm{C} \cdot \mathrm{min}^{-1} \mathrm{un}$ der nitrogen flow from 25 to $130^{\circ} \mathrm{C}$ for DSC measurement. Linear sweep voltammograms were carried out on an electrochemical workstation (Autolab 320, Metrohm, Switzerland) at $25^{\circ} \mathrm{C}$ at a scan rate of $5 \mathrm{mV} \mathrm{s}^{-1}$, and were measured by a two-electrode system equipped with a $1 \mathrm{~mm}$ radius platinum disk electrode (CHI102, CH Instruments Inc., USA) as the counter electrode and a reference electrode, a $5.0 \mu \mathrm{m}$ radius platinum ultramicroelectrode $(\mathrm{CHI} 107, \mathrm{CH}$ Instruments Inc., USA) as the working electrode. 


\section{Photovoltaic characterization}

The current density-voltage $(J-V)$ measurements of DSSCs with the active area of $0.16 \mathrm{~cm}^{2}$ with black mask were measured by a Keithley 2420 digital source meter (Keithley, USA) and controlled by Test point software under a 450 W xenon lamp (Orial, USA) with a filter (AM 1.5, 100 $\mathrm{mW} \mathrm{cm}{ }^{-2}$ ). The photocurrent action spectra were recorded on the incidental photon-to-electron conversion efficiency (IPCE) measurement kit consisting of a $300 \mathrm{~W}$ xenon lamp (69911, Newport, USA), a 1/4 m monochromator (74125 Oriel Cornerstone 260, Newport, USA), a dual channel power meter (2931-C, Newport, USA) and the calibrated UV silicon photodetector (71675, Newport, USA). The electrochemical impedance spectroscopy (EIS) data were recorded using an electrochemical workstation (Autolab 320, Metrohm, Switzerland). To measure the impedance, a direct-current bias at $700 \mathrm{mV}$, and perturbation amplitude of $10 \mathrm{mV}$ in the frequency range from $10 \mathrm{mHz}$ to $1 \mathrm{MHz}$ were applied in the dark. The obtained EIS data were fitted to a transmission line equivalent circuit model with Z-View software (v2.8b, Scribner Associates, USA). Intensity-modulated measurements were measured by controlled intensity modulated photocurrent/photovoltage spectroscopy (IMPS/IMVS) measurements using an electrochemical workstation (IM6e, Zahner, Germany) with light emitting diodes (LED) $(\lambda=610 \mathrm{~nm})$ driven by a source supply (XPOT, Zahner, Germany). A small accomponent is $10 \%$ or less than that of the dc component provided by the LED and the frequency range was from $3 \mathrm{kHz}$ to $300 \mathrm{mHz}$. Hermetically sealed cells were used for long-term stability tests. The cells were stored in the oven at $50^{\circ} \mathrm{C}$ for thermal stress experiment. Moreover, the successive one sun light soaking experiment was also carried out. DSSCs covered with a UV cut-off filter (up to $394 \mathrm{~nm}$ ) were irradiated at the open circuit under one sun (AM 1.5) light soaking (XQ3000, $100 \mathrm{~mW} \mathrm{~cm}^{-2}$, Shanghai B.R. Science Instrument Co., Ltd, China) and the ambient temperature was set to $50^{\circ} \mathrm{C}$ during the light soaking experiment. $J-V$ measurements were carried out at room temperature after allowing these cells to cool down and equilibrate for $30 \mathrm{~min}$.

\section{RESULTS AND DISCUSSION}

Because of the self-assembly of the gelator through the noncovalent interaction such as hydrogen bond and van der Waals force among the gelator molecules, the crosslinking gel network is formed in the gel electrolyte [12,27]. The in situ gelation process of LOMG in the MePN solvent was observed by polarized optical light microscopy (POM) in the same area of the sample. First, the gel was heated to $130^{\circ} \mathrm{C}$

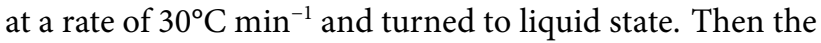
hot solution was cooled to $10^{\circ} \mathrm{C}$ at a rate of $1^{\circ} \mathrm{C} \mathrm{min}{ }^{-1}$. The photographs of Figs 1a-d were respectively taken during the cooling process at $122.3,122.0,111.7$ and $90.4^{\circ} \mathrm{C}$, which

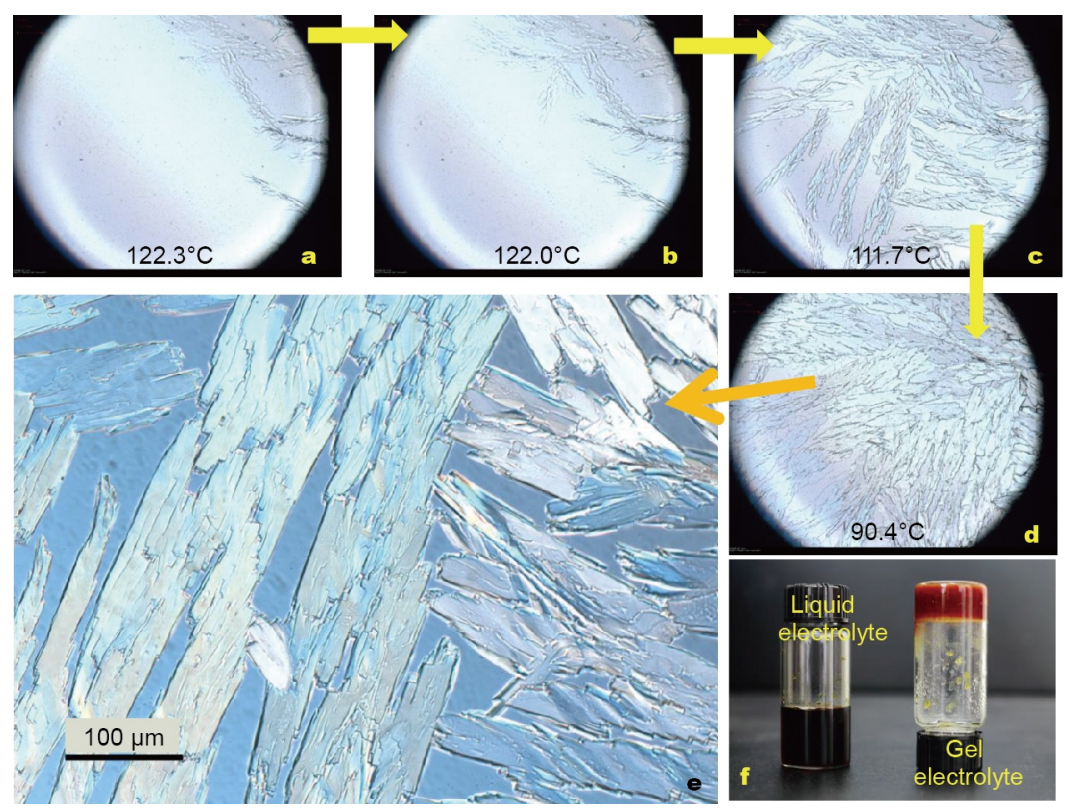

Figure 1 Optical micrographs between crossed polarizers showing the in situ assembly process of the gel network at (a) $122.3^{\circ} \mathrm{C},(\mathrm{b}) 122.0^{\circ} \mathrm{C},(\mathrm{c})$ $111.7^{\circ} \mathrm{C}$, (d) $90.4^{\circ} \mathrm{C}$ in the MePN solvent, (e) the amplified photograph of the assembled gel network and fibers, and (f) the photographs of liquid electrolyte and gel electrolyte. 
show the self-assembly process of the gel network. As shown in Fig. 1e, the amplifying photograph shows the size and sheet fibers of the crosslinking network. In addition, we can observe that the gel electrolyte exhibits certain mechanical properties like solid materials in Fig. If.

The diffusion rates of iodide $\left(\mathrm{I}^{-}\right)$and triiodide $\left(\mathrm{I}_{3}{ }^{-}\right)$in electrolytes have very important influence on the photovoltaic performance of the DSSCs [28]. According to the linear sweep voltammograms (Fig. 2) and the apparent diffusion coefficients $\left(D_{\text {app }}\right)$ which were calculated by Equation (1), the diffusions of $\mathrm{I}^{-}$and $\mathrm{I}_{3}{ }^{-}$in the electrolytes were investigated in detail [29].

$$
D_{\text {app }}=I_{\text {ss }} / 4 n F r c \text {, }
$$

where $F$ is the Faraday constant, $n$ is the number of the electron in the electrode reaction, $r$ is the radius of platinum ultramicroelectrode, $c$ is the molar concentrations of $\mathrm{I}_{3}{ }^{-}$and $\mathrm{I}^{-}$. Due to the different capacitances between the liquid and gel electrolyte, there are differences between both electrolytes before reaching the steady-state condition shown in Fig. 2. When the system reached the steady-state condition, the steady-state limiting current $\left(I_{\mathrm{ss}}\right)$ in the lower plateau refers to the electrochemical reduction of $\mathrm{I}_{3}{ }^{-}$, and the $I_{s s}$ in the upper plateau reflects the electrochemical oxidation of $\mathrm{I}^{-}$. Furthermore, because the crosslinking network of the gel electrolyte hinders the transportation of $\mathrm{I}_{3}{ }^{-} / \mathrm{I}^{-}$redox couple, $D_{\text {app }}$ values of $\mathrm{I}_{3}{ }^{-}$and $\mathrm{I}^{-}$in the gel electrolyte are lower than those of the liquid electrolyte in Table 1 , which leads to more power dissipation in the gel electrolyte based QS-DSSC.

The inset in Fig. 2 shows the DSC curve of the gel electrolyte and the $T_{\text {gel }}$. When the gel electrolyte was heated to $100^{\circ} \mathrm{C}$, the gel network started to collapse, and the gel completely transformed into liquid state under $108^{\circ} \mathrm{C}$. This high $T_{\text {gel }}$ ensures the gel state of the electrolyte at the operating temperature of the devices, which is crucial for the long-term stability of the DSSC.

The EIS and IMPS/IMVS were used to study the kinetic process of electron transport and recombination in the QS-DSSC [30,31]. As shown in Fig. 3a, the Nyquist plots for the two devices can be observed and fitted according to the equivalent circuits in the inset of Fig. 3a, The EIS parameters of DSSCs such as the series resistance $\left(R_{s}\right)$, the charge transfer resistance $\left(R_{\mathrm{ct}}\right)$ related to electron recom-

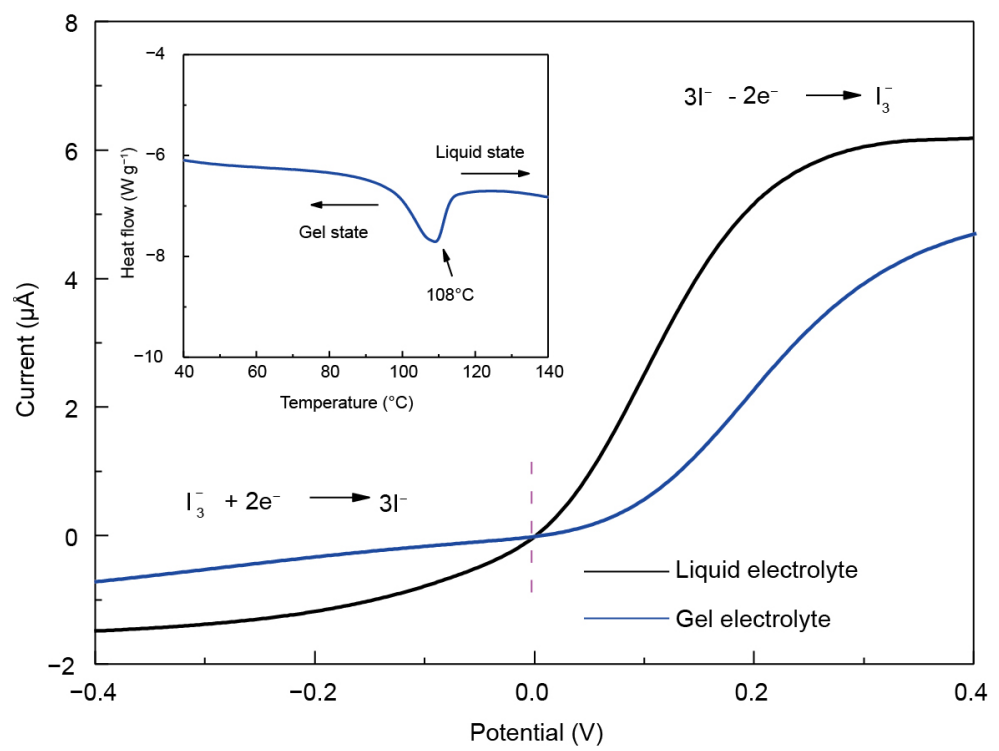

Figure 2 Linear sweep voltammograms of the liquid and gel electrolyte with a Pt ultramicroelectrode and a platinum disk electrode at $25^{\circ} \mathrm{C}$. The inset shows DSC thermograms of the gel electrolyte.

Table 1 The steady-state limiting currents $\left(I_{\mathrm{ss}}\right)$ and apparent diffusion coefficients $\left(D_{\text {app }}\right)$ of $\mathrm{I}^{-}$and $\mathrm{I}_{3}^{-}$in the liquid and gel electrolytes

\begin{tabular}{ccccc}
\hline Electrolyte & $I_{\mathrm{ss}}\left(\mathrm{I}_{3}^{-}\right)$ & $I_{\mathrm{ss}}\left(\mathrm{I}^{-}\right)$ & $D_{\text {app }}\left(\mathrm{I}_{3}^{-}\right)$ & $D_{\text {app }}\left(\mathrm{I}^{-}\right)$ \\
$\left(10^{-7} \mathrm{~A}\right)$ & $\left(10^{-6} \mathrm{~cm}^{2} \mathrm{~s}^{-1}\right)$ & 4.35 \\
\hline Liquid & 1.55 & 6.15 & 4.02 & 3.10 \\
Gel & 0.88 & 4.39 & 2.28 & 3.10 \\
\hline
\end{tabular}



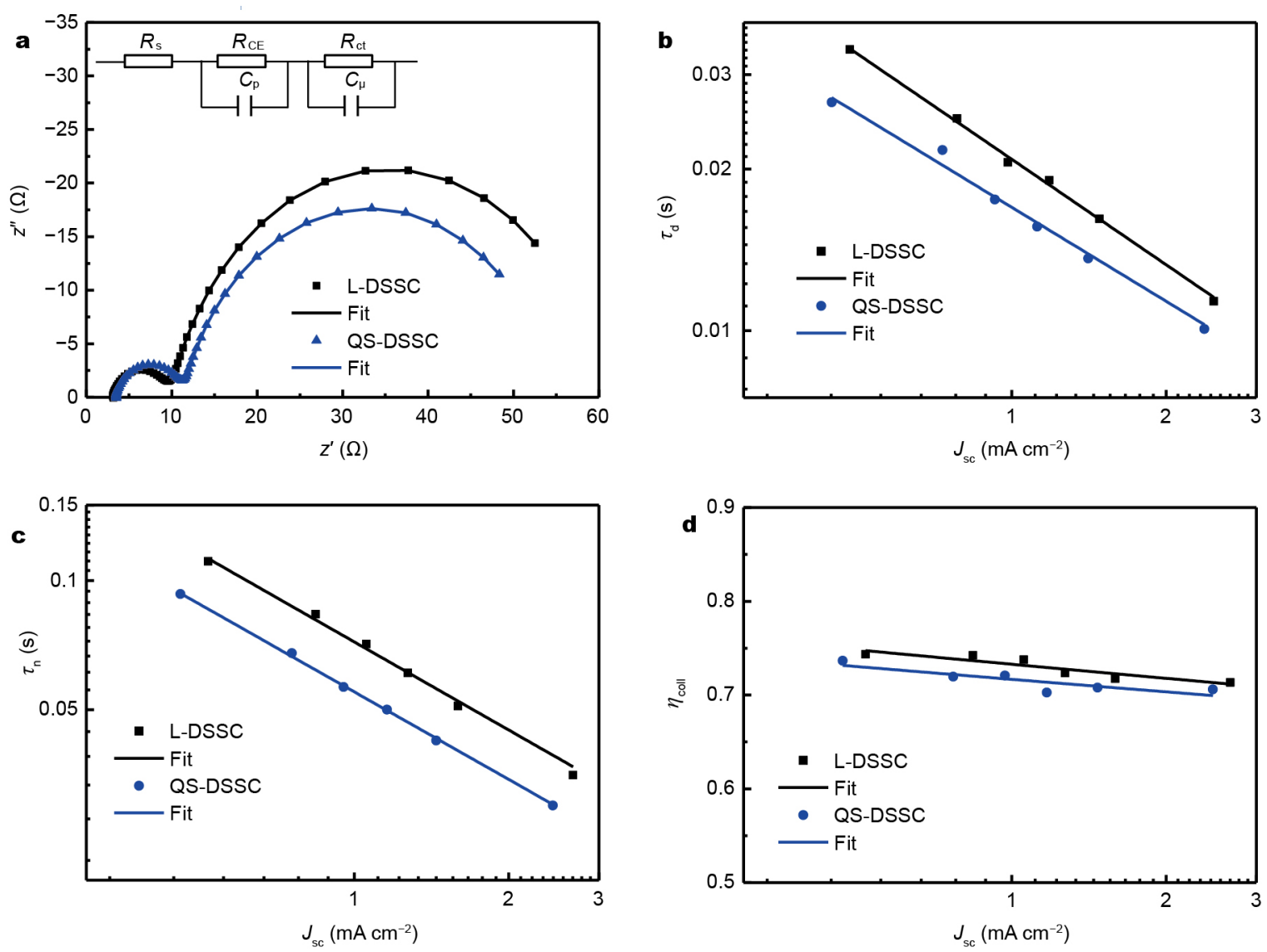

Figure 3 (a) Electrochemical impedance spectroscopies (Nyquist plots), (b) light intensity dependence of the electron transport time $\left(\tau_{\mathrm{d}}\right)$, (c) the electron recombination lifetime $\left(\tau_{\mathrm{n}}\right),(\mathrm{d})$ the electron collection efficiency $\left(\eta_{\text {coll }}\right)$ and the lines showing the fitted results.

bination processes occurring at photoelectrode/electrolyte interfaces, the capacitance of this interface $\left(C_{\mu}\right)$ are listed in Table 2 along with the calculated values of electron lifetime $\left(\tau_{\mathrm{n}(\mathrm{EIS})}=R_{\mathrm{ct}} C_{\mu}\right)$ which reflects the electron recombination at the $\mathrm{TiO}_{2}$ photoelectrode/electrolyte interface. Generally speaking, the $R_{\mathrm{ct}}$ of QS-DSSC is smaller than that of L-DSSC, as well as the $\tau_{\mathrm{n}(\mathrm{EIS})}$, which means that a faster electron recombination process between the injected electrons and the $\mathrm{I}_{3}{ }^{-}$occurred in the gel electrolyte. This phenomenon can be attributed to the conduction band electrons of the $\mathrm{TiO}_{2}$ photoelectrode that are captured by the increased molar concentrations of $\mathrm{I}_{3}{ }^{-}$at the $\mathrm{TiO}_{2}$ photoelectrode/electrolyte interface resulted from the decreased diffusion rate of $\mathrm{I}_{3}{ }^{-}$in the QS-DSSC.

The electron transport time $\left(\tau_{\mathrm{d}}\right)$ reflects the electron transport of the injected electrons through the $\mathrm{TiO}_{2}$ photoelectrode and the electron recombination lifetime $\left(\tau_{\mathrm{n}}\right)$ reflects the lifetime of photogenerated electrons in mesoporous $\mathrm{TiO}_{2}$ nanocrystalline films in DSSC, which can be obtained by IMPS/IMVS measurement. It is known that
Table 2 The fitting results of EIS parameters for L-DSSC and QS-DSSC

\begin{tabular}{ccccc}
\hline Cell & $R_{\mathrm{s}}(\Omega)$ & $R_{\mathrm{ct}}(\Omega)$ & $C_{\mu}(\mu \mathrm{F})$ & $\tau_{\mathrm{n}(\mathrm{EIS})}(\mathrm{s})$ \\
\hline L-DSSC & 3.019 & 35.43 & 1802 & 0.0638 \\
QS-DSSC & 3.258 & 29.75 & 1788 & 0.0531 \\
\hline
\end{tabular}

the adsorption of $\mathrm{Li}^{+}$on the surface of $\mathrm{TiO}_{2}$ films can increase the amount of surface traps and deepen the surface state energy distribution, which leads to deceleration of the electron transport and charge recombination $[32,33]$. The interaction between the amide carbonyl groups of LOMG and $\mathrm{Li}^{+}$in the QS-DSSC results in a decreased adsorption of $\mathrm{Li}^{+}$on the surface of the mesoporous $\mathrm{TiO}_{2}$ film, which can be observed that the $\tau_{\mathrm{d}}$ of the QS-DSSC is shorter than that of the L-DSSC in Fig. 3b [34]. Moreover, as shown in Fig. $3 c$, the $\tau_{\mathrm{n}}$ of the L-DSSC is longer than that of the QS-DSSC, which reveals an accelerated electron recombination process between the injected electrons and $\mathrm{I}_{3}{ }^{-}\left(D_{\text {app }}\right.$ (liquid electrolyte) $>D_{\text {app }}$ (gel electrolyte)) in QS-DSSC on account of a decelerated diffusion rate of $\mathrm{I}_{3}{ }^{-}$from the $\mathrm{TiO}_{2}$ 
photoelectrode/electrolyte interface to the Pt counter electrode. To estimate the competition between electron transport in the $\mathrm{TiO}_{2}$ photoanode and electron recombination for the DSSCs based on different electrolytes, electron collection efficiency $\left(\eta_{\text {coll }}\right)$ was calculated by Equation ( 2$)$ and shown in Fig. 3d [35]:

$$
\eta_{\mathrm{coll}}=1-\frac{\tau_{\mathrm{d}}}{\tau_{\mathrm{n}}}
$$

It can be seen that the $\eta_{\text {coll }}$ of L-DSSC is slightly higher than that of QS-DSSC, which has influence on the IPCE and the short-circuit current density $\left(J_{s c}\right)$.

The $\mathrm{TiO}_{2}$ conduction band edge is one of decisive factors to the open circuit voltage $\left(V_{o c}\right)$. However, the surface of the mesoporous $\mathrm{TiO}_{2}$ film was partly occupied by $\mathrm{Li}^{+}$existed in the electrolyte, which can result in a positive shift of the $\mathrm{TiO}_{2}$ conduction band edge. In QS-DSSC, the $\mathrm{Li}^{+}$ can interact with the amide carbonyl groups of the gelators leading to a decrease in the adsorption of $\mathrm{Li}^{+}$onto the $\mathrm{TiO}_{2}$ surface [36,37], which causes a negative shift in the $\mathrm{TiO}_{2}$ conduction band edge, and the difference in the conduction band edges of the DSSCs with different electrolytes are given in Fig. 4. The relationship between $V_{\text {oc }}$ and $\ln Q$ can be expressed as the following Equation (3) [38,39]:

$$
V_{\mathrm{oc}}=V_{\mathrm{c}}+m_{\mathrm{c}} \ln Q,
$$

where $V_{c}$ is the vertical intercept, $Q$ is the photoinduced charge in the mesoporous $\mathrm{TiO}_{2}$ films, and $m_{\mathrm{c}}$ is the slop rate. As shown in Fig. 4, the $\mathrm{TiO}_{2}$ conduction band edge of QS-DSSC shifts negatively in comparing with that of L-DSSC. A negative shift of the $\mathrm{TiO}_{2}$ conduction band edge in QS-DSSC contributes to $V_{\text {oc }}$ but leads to a decreased electron injection efficiency $\left(\eta_{\text {inj }}\right)$, which is vital for the photocurrent of DSSCs.

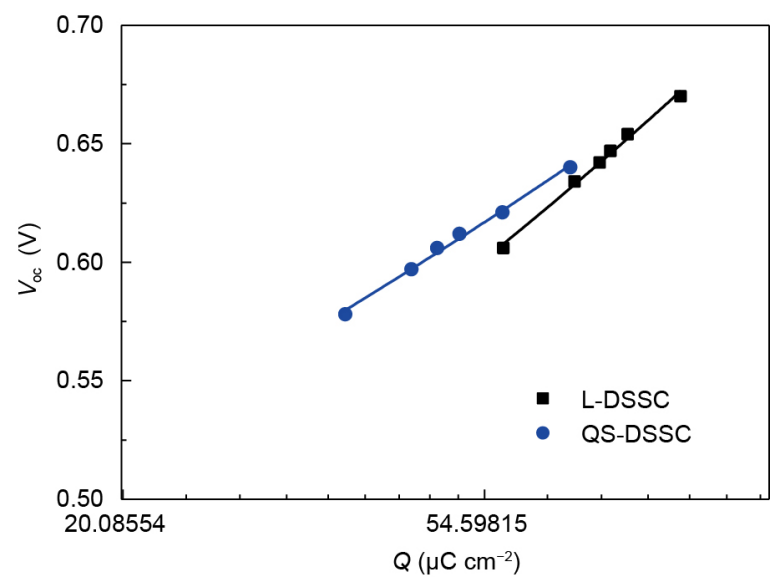

Figure 4 Voltage dependence of the photoinduced electron density in the L-DSSC and QS-DSSC.
The IPCE is defined as the ratio of the number of electrons in the external circuit produced by an incident photon at a given wavelength, using Equation (4) [40]:

$$
\mathrm{IPCE}=\eta_{\mathrm{lh}} \times \eta_{\text {inj }} \times \eta_{\text {coll }},
$$

where $\eta_{\mathrm{lh}}$ is the light-harvesting efficiency determined by the loading and extinction coefficient of the dye. Considering the same preparation process of the dyed $\mathrm{TiO}_{2}$ films for both the L-DSSC and the QS-DSSC, the difference in $\eta_{\mathrm{lh}}$ can be negligible. According to the result shown in Fig. $3 \mathrm{~d}, \eta_{\text {coll }}$ of the L-DSSC is slight higher than that of QS-DSSC. In addition, the negative shift of the $\mathrm{TiO}_{2}$ conduction band edge in QS-DSSC could lead to a decreased $\eta_{\text {inj. }}$. Consequently, the L-DSSC exhibits higher IPCE than the QS-DSSC, which is shown in the inset of Fig. 5. In addition, $J_{\text {sc }}$ can be estimated by Equation (5) [41]:

$$
J_{\mathrm{sc}}=q \times \operatorname{IPCE} \times I_{\mathrm{o}},
$$

where $q$ is the elementary charge, $I_{\mathrm{o}}$ is the light intensity. The photocurrent density-voltage curves at AM 1.5 (100 $\mathrm{mW} \mathrm{cm} \mathrm{cm}^{-2}$ ) and in the dark condition for the L-DSSC and QS-DSSC are shown in Fig. 5, and the relevant photovoltaic parameters are listed in Table 3 . The $J_{\mathrm{sc}}$ of QS-DSSC is lower than that of L-DSSC due to the decreased IPCE of the QS-DSSC. In dark condition, the dark current of QS-

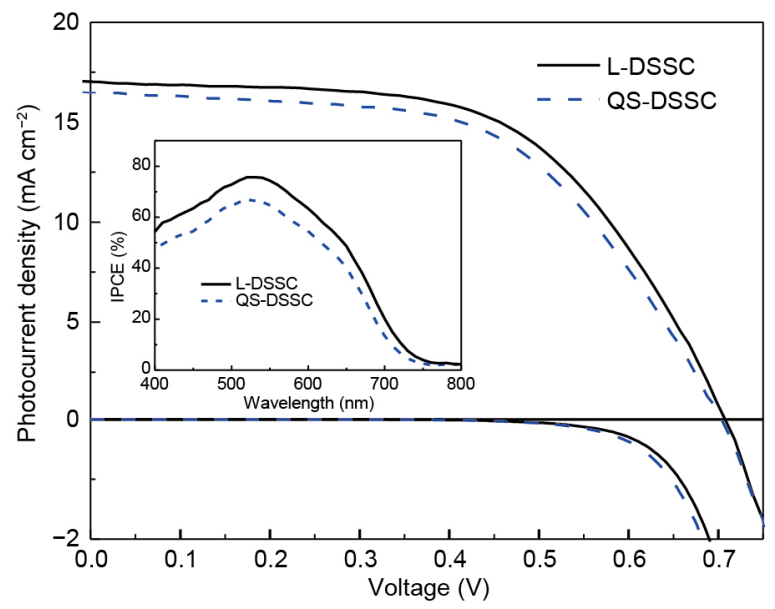

Figure $5 \mathrm{~J}$ - $V$ curves at AM $1.5\left(100 \mathrm{~mW} \mathrm{~cm}^{-2}\right)$ and under dark condition. The inset shows the IPCE spectra of L-DSSC and QS-DSSC.

Table 3 Photovoltaic parameters of L-DSSC and QS-DSSC at AM 1.5 $\left(100 \mathrm{~mW} \mathrm{~cm}^{-2}\right)$

\begin{tabular}{ccccc}
\hline Cell & $V_{\mathrm{oc}}(\mathrm{mV})$ & $J_{\mathrm{sc}}\left(\mathrm{mA} \mathrm{cm}^{-2}\right)$ & $\mathrm{FF}(\%)$ & PCE $(\%)$ \\
\hline L-DSSC & 707.9 & 17.12 & 57 & 6.91 \\
QS-DSSC & 703.0 & 16.57 & 57 & 6.50 \\
\hline
\end{tabular}


DSSC is higher than that of L-DSSC, which is corresponding with the results obtained by EIS measurement. Although the $\mathrm{TiO}_{2}$ conduction band edge in QS-DSSC moves to the negative direction, the acceleration of the electron recombination at the $\mathrm{TiO}_{2}$ photoelectrode/electrolyte interface plays a leading role in the $V_{\text {oc }}$ [42]. As a result, the $V_{\text {oc }}$ of the L-DSSC is slightly higher than that of QS-DSSC. Consequently, the QS-DSSC shows a decreased photoelectric conversion efficiency (PCE) of $6.50 \%$, which is comparable to that of the L-DSSC $(\mathrm{PCE}=6.91 \%)$.

Stability is a crucial factor for the application of DSSCs. As shown in Fig. 6, the QS-DSSC exhibits excellent stability during the accelerated aging process of successive one sun light soaking with UV cutoff filter at $50^{\circ} \mathrm{C}$ for $1000 \mathrm{~h}$. After the continuous accelerated aging test, the efficiency of QS-DSSC exhibits no obvious degradation after $1000 \mathrm{~h}$, whereas the efficiency of the L-DSSC degrades by nearly $20 \%$ of its initial efficiency. In consideration of little reductions in $V_{\text {oc }}$ and FF of the devices, the decrease of efficiency is mainly attributed to the reduction of $J_{\text {sc }}$. The result of this work demonstrates that this gel electrolyte can effectively promote the stability of the device due to the high $T_{\text {gel }}$ of the gel electrolyte whose crosslinking gel network can
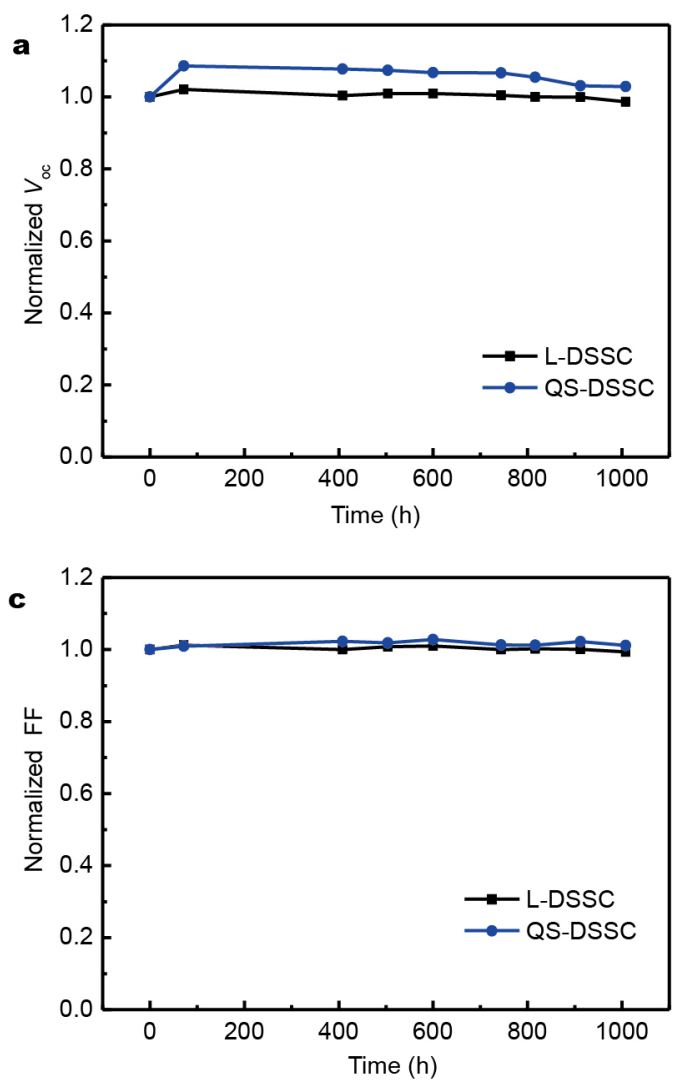

effectively suppress evaporation and leakage of the liquid electrolyte at the operating temperature.

\section{CONCLUSION}

In summary, a stable QS-DSSC was prepared by using the gel electrolyte containing $N, N^{\prime}$-1,5-pentanediylbis-dodecanamide as LMOG. On one hand, the self-assembled gel network hinders the diffusion of $\mathrm{I}_{3}^{-}$from the $\mathrm{TiO}_{2}$ photoelectrode/electrolyte interface to the Pt counter electrode, which accelerates the electron recombination at the $\mathrm{TiO}_{2}$ photoelectrode/electrolyte interface and decreases the $V_{\text {oc }}$. On the other hand, since the $\mathrm{Li}^{+}$interacts with the amide carbonyl groups of the gelators, the adsorption of $\mathrm{Li}^{+}$onto the $\mathrm{TiO}_{2}$ surface decreases. As a result, the $\mathrm{TiO}_{2}$ conduction band edge of QS-DSSC shifts to a negative potential, which contributes to $V_{\text {oc }}$. Consequently, the $V_{\text {oc }}$ of the L-DSSC is slightly higher than that of the QS-DSSC. Moreover, owing to the decreased IPCE and $J_{\mathrm{sc}}$ of QS-DSSC, the photoelectric conversion efficiency (PCE) of QS-DSSC $(6.50 \%)$ is lower than that of L-DSSC (6.91\%). Importantly, the QS-DSSC exhibits excellent stability during the accelerated aging test. After the continuous accelerated aging, the efficiency of QS-DSSC exhibits no obvious decrease
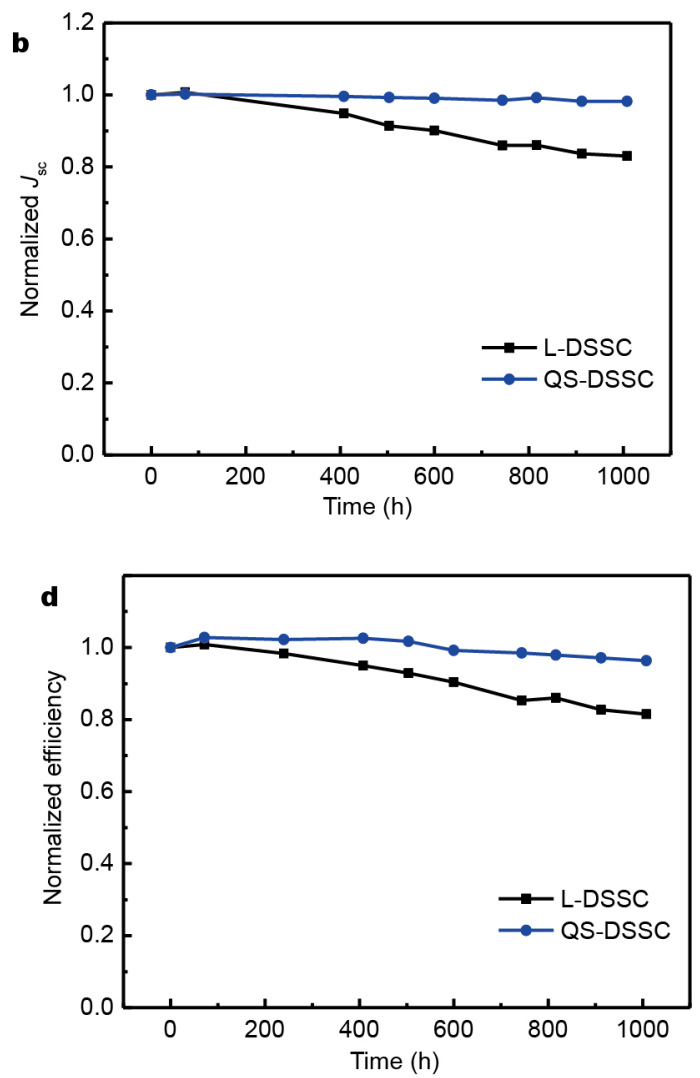

Figure 6 Normalized efficiency variation with the L-DSSC and QS-DSSC at successive one sunlight soaking with UV cutoff filter at $50^{\circ} \mathrm{C}$ for $1000 \mathrm{~h}$. 
after $1000 \mathrm{~h}$, whereas the efficiency of the L-DSSC degrades by nearly $20 \%$ of its initial efficiency. This is because that the high $T_{\text {gel }}\left(108^{\circ} \mathrm{C}\right)$ of gel electrolyte ensures a good intrinsic stability and the crosslinking gel network can suppress evaporation and leakage of the liquid electrolyte. These findings are very vital to the application and commercialization of QS-DSSCs.

Received 30 June 2016; accepted 1 August 2016; published online 26 August 2016

1 O'Regan B, Grätzel M. A low-cost, high-efficiency solar cell based on dye-sensitized colloidal $\mathrm{TiO}_{2}$ films. Nature, 1991, 353: 737-740

2 Grätzel M. All surface and no bulk. Nature, 1991, 349: 740-741

3 Mathew S, Yella A, Gao P, et al. Dye-sensitized solar cells with $13 \%$ efficiency achieved through the molecular engineering of porphyrin sensitizers. Nat Chem, 2014, 6: 242-247

4 Hagfeldt A, Boschloo G, Sun L, et al. Dye-sensitized solar cells. Chem Rev, 2010, 110: 6595-6663

5 Ye M, Wen X, Wang M, et al. Recent advances in dye-sensitized solar cells: from photoanodes, sensitizers and electrolytes to counter electrodes. Mater Today, 2015, 18: 155-162

6 Kakiage K, Aoyama Y, Yano T, et al. Highly-efficient dye-sensitized solar cells with collaborative sensitization by silyl-anchor and carboxy-anchor dyes. Chem Commun, 2015, 51: 15894-15897

7 Lei BX, Fang WJ, Hou YF, et al. All-solid-state electrolytes consisting of ionic liquid and carbon black for efficient dye-sensitized solar cells. J Photochem Photobio A-Chem, 2010, 216: 8-14

8 Docampo P, Guldin S, Stefik M, et al. Control of solid-state dye-sensitized solar cell performance by block-copolymer-directed $\mathrm{TiO}_{2}$ synthesis. Adv Funct Mater, 2010, 20: 1787-1796

9 Zhang XH, Wang SM, Xu ZX, et al. Poly(o-phenylenediamine)/MWNTs composite film as a hole conductor in solid-state dye-sensitized solar cells. J Photochem Photobio A-Chem, 2008, 198: 288-292

10 Patel R, Seo JA, Koh JH, et al. Dye-sensitized solar cells employing amphiphilic poly(ethylene glycol) electrolytes. J Photochem Photobio A-Chem, 2011, 217: 169-176

11 Anantharaj G, Joseph J, Selvaraj M, et al. Fabrication of stable dye sensitized solar cell with gel electrolytes using poly(ethylene oxide)-poly(ethylene glycol). Electrochim Acta, 2015, 176: 1403-1409

12 Tao L, Huo Z, Ding Y, et al. Gel electrolyte materials formed from a series of novel low molecular mass organogelators for stable quasisolid-state dye-sensitized solar cells. J Mater Chem A, 2014, 2: 15921-15930

13 Mohan VM, Murakami K, Kono A, et al. Poly(acrylonitrile)/activated carbon composite polymer gel electrolyte for high efficiency dye sensitized solar cells. J Mater Chem A, 2013, 1: 7399-7407

14 Chen W, Qiu Y, Yan K, et al. Surfactant directed self-assembly of size-tunable mesoporous titanium dioxide microspheres and their application in quasi-solid state dye-sensitized solar cells. J Power Sources, 2011, 196: 10806-10816

15 Hanabusa K, Hiratsuka K, Kimura M, et al. Easy preparation and useful character of organogel electrolytes based on low molecular weight gelator. Chem Mater, 1999, 11: 649-655

16 Huo Z, Tao L, Wang S, et al. A novel polysulfide hydrogel electrolyte based on low molecular mass organogelator for quasi-solid-state quantum dot-sensitized solar cells. J Power Sources, 2015, 284: $582-587$
17 Dissanayake MAKL, Thotawatthage CA, Senadeera GKR, et al. Efficiency enhancement by mixed cation effect in dye-sensitized solar cells with PAN based gel polymer electrolyte. J Photochem Photobio A-Chem, 2012, 246: 29-35

18 Lan Z, Wu J, Lin J, et al. Influence of molecular weight of PEG on the property of polymer gel electrolyte and performance of quasisolid-state dye-sensitized solar cells. Electrochim Acta, 2007, 52: 6673-6678

19 Suriwong $\mathrm{T}$, Thongtem $\mathrm{T}$, Thongtem $\mathrm{S}$. $\mathrm{CuAlO}_{2}$ powder dispersed in composite gel electrolyte for application in quasi-solid state dyesensitized solar cells. Mater Sci Semicond Proc, 2015, 39: 348-354

20 Lodermeyer F, Costa RD, Casillas R, et al. Carbon nanohorn-based electrolyte for dye-sensitized solar cells. Energy Environ Sci, 2015, 8: $241-246$

21 Wang G, Yang H, Cheuk S, et al. Synthesis and self-assembly of 1-deoxyglucose derivatives as low molecular weight organogelators. Beilstein J Org Chem, 2011, 7: 234-242

22 Suzuka M, Hayashi N, Sekiguchi T, et al. A quasi-solid state dssc with $10.1 \%$ efficiency through molecular design of the charge-separation and -transport. Sci Rep, 2016, 6: 28022

23 Lee HS, Bae SH, Jo Y, et al. A high temperature stable electrolyte system for dye-sensitized solar cells. Electrochim Acta, 2010, 55: 7159-7165

24 Wu JH, Lan Z, Lin JM, et al. A novel thermosetting gel electrolyte for stable quasi-solid-state dye-sensitized solar cells. Adv Mater, 2007, 19: 4006-4011

25 Tao L, Huo Z, Ding Y, et al. High-efficiency and stable quasisolid-state dye-sensitized solar cell based on low molecular mass organogelator electrolyte. J Mater Chem A, 2015, 3: 2344-2352

26 Shi CW, Dai SY, Wang KJ, et al. Optimization of 1,2-dimethyl3-propylimidazolium iodide concentration in dye-sensitized solar cells. Acta Phys Chim Sin, 2005, 21: 534-538

27 Tao L, Huo Z, Dai S, et al. Stable quasi-solid-state dye-sensitized solar cell using a diamide derivative as low molecular mass organogelator. J Power Sources, 2014, 262: 444-450

28 Pringle JM, Armel V. The influence of ionic liquid and plastic crystal electrolytes on the photovoltaic characteristics of dye-sensitised solar cells. Int Rev Phys Chem, 2011, 30: 371-407

29 Van de Lagemaat J, Park NG, Frank AJ. Influence of electrical potential distribution, charge transport, and recombination on the photopotential and photocurrent conversion efficiency of dye-sensitized nanocrystalline $\mathrm{TiO}_{2}$ solar cells: a study by electrical impedance and optical modulation techniques. J Phys Chem B, 2000, 104: 2044-2052

30 Bisquert J. Theory of the impedance of electron diffusion and recombination in a thin layer. J Phys Chem B, 2002, 106: 325-333

31 Barnes PRF, O'Regan BC. Electron recombination kinetics and the analysis of collection efficiency and diffusion length measurements in dye sensitized solar cells. J Phys Chem C, 2010, 114: 19134-19140

32 Nelson J, Chandler RE. Random walk models of charge transfer and transport in dye sensitized systems. Coordin Chem Rev, 2004, 248: 1181-1194

33 Kou D, Liu W, Hu L, et al. Cooperative effect of adsorbed cations on electron transport and recombination behavior in dye-sensitized solar cells. Electrochim Acta, 2013, 100: 197-202

34 Huo Z, Tao L, Dai S, et al. Quasi-solid-state dye sensitized solar cells using supramolecular gel electrolyte formed from two-component low molecular mass organogelators. Sci China Mater, 2015, 58: 447-454

35 Grätzel M. Solar energy conversion by dye-sensitized photovoltaic cells. Inorg Chem, 2005, 44: 6841-6851 
Wang QY, Lu J, Liao SM, et al. Unconventional interaction forces in protein and protein-ligand systems and their impacts to drug design. Curr Top Med Chem, 2013, 13: 1141-1151

37 Liu J, Xia X, Li Y, et al. Theoretical study on the interaction of glutathione with group IA $\left(\mathrm{Li}^{+}, \mathrm{Na}^{+}, \mathrm{K}^{+}\right)$, IIA $\left(\mathrm{Be}^{2+}, \mathrm{Mg}^{2+}, \mathrm{Ca}^{2+}\right)$, and IIIA $\left(\mathrm{Al}^{3+}\right)$ metal cations. Struct Chem, 2013, 24: 251-261

38 Ren X, Feng Q, Zhou G, et al. Effect of cations in coadsorbate on charge recombination and conduction band edge movement in dye-sensitized solar cells. J Phys Chem C, 2010, 114: 7190-7195

39 Huang SY, Schlichthörl G, Nozik AJ, et al. Charge recombination in dye-sensitized nanocrystalline $\mathrm{TiO}_{2}$ solar cells. J Phys Chem B, 1997, 101: 2576-2582

40 Zhang W, Zhu R, Li F, et al. High-performance solid-state organic dye sensitized solar cells with P3HT as hole transporter. J Phys Chem C, 2011, 115: 7038-7043

41 Tachibana Y, Hara K, Sayama K, et al. Quantitative analysis of lightharvesting efficiency and electron-transfer yield in ruthenium-dyesensitized nanocrystalline $\mathrm{TiO}_{2}$ solar cells. Chem Mater, 2002, 14: 2527-2535

42 Fan J, Li L, Rao HS, et al. A novel metal-organic gel based electrolyte for efficient quasi-solid-state dye-sensitized solar cells. J
Mater Chem A, 2014, 2: 15406

Acknowledgments This work was supported by the National High Technology Research and Development Program of China (2015AA050602), the National Natural Science Foundation of China (21103197, 21403247, 61404142 and 21273242), the National Basic Research Program of China (2015CB932200), the project of Scientific and Technological Support Program in Jiangsu province (BE2014147-4), and Beijing Municipal Science and Technology Project (Z141100003314003).

Author contributions Wang L performed the main experiments and wrote this manuscript. Huo $\mathrm{Z}$ and Tao L directly guided and conducted this research including the design, modifying and polishing work related to this manuscript. Dai S supervised the projects and carefully reviewed and modified this manuscript. Zhu J, Chen S and Pan X provided help in the fabrication of devices and methods of characterization. All authors contributed to the general discussion about this work.

Conflict of interest The authors declare that they have no conflict of interest.

Supplementary information Supplementary data are available in the online version of the paper. 

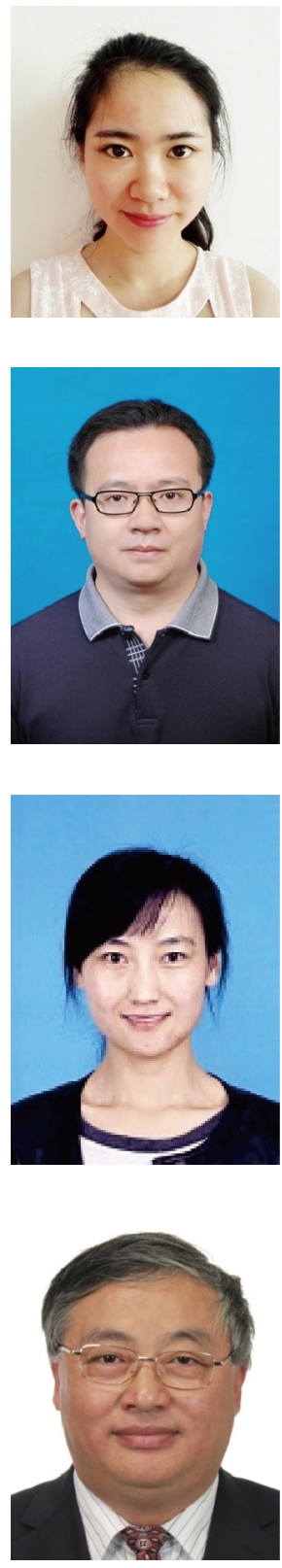

Lu Wang was born in 1992. She obtained her BSc degree in materials chemistry from Anhui Normal University in 2014, and she is currently a Master candidate at the University of Science and Technology of China under the supervision of Prof. Zhipeng Huo. Her research interests mainly focus on functional electrolytes, characterization and application of organic compounds, electrochemical analysis for energy conversion devices.
Zhipeng Huo was born in 1982. He is an associate researcher of Hefei Institutes of Physical Science, Chinese Academy of Sciences. He obtained his BSc degree in chemical engineering and technology from Beijing University of Chemical Technology in 2004, and PhD degree in materials physics and chemistry from Graduate University of Chinese Academy of Sciences in 2009. His current research interests mainly focus on functional materials, devices and electrochemistry for energy conversion and storage devices.
Li Tao was born in 1983. She is a Lecturer of Hubei University. She obtained her PhD degree in materials physics and chemistry from the University of Chinese Academy of Sciences in 2015. Her research interests mainly focus on synthesis, characterization and application of organic compounds, and electrochemical analysis for energy conversion devices.
Songyuan Dai is a professor and Dean of the School of Renewable Energy, North China Electric Power University. He obtained his BSc degree in physics from Anhui Normal University in 1987, and MSc and PhD degrees in plasma physics from the Institute of Plasma Physics, Chinese Academy of Sciences in 1991 and 2001. His research interests mainly focus on next-generation solar cells including dye-sensitized solar cells, quantum dot solar cells, perovskite solar cells, etc.

\section{有机小分子自组装凝胶网络对准固态染料敏化太阳电池电子动力学的影响机制}

王露 ${ }^{1,2}$, 霍志鹏 ${ }^{{ }^{*}}$, 桃李 $3^{*}$, 朱俊 $^{1}$, 陈双宏 ${ }^{1}$, 潘旭 ${ }^{1}$, 戴松元 ${ }^{1,4^{*}}$

摘要 本文合成了 $N, N^{\top}-1,5$-戊二基双月桂酰胺作为有机小分子凝胶剂, 并将其应用于准固态染料敏化太阳电池(QS-DSSC)的电解质材料中. 通过偏光显微镜观察到凝胶剂分子在液态电解质中形成交联凝胶网络的原位自组装过程. 一方面, 凝胶网络对氧化还原电对物理扩散的 阻碍效应, 加速了电解质 $/ \mathrm{TiO}_{2}$ 光阳极界面的电子复合. 另一方面, $\mathrm{Li}^{+}$与凝胶剂分子的酰胺基团发生锂键相互作用, 减少了 $\mathrm{Li}^{+}$在 $\mathrm{TiO}_{2}$ 表面的 吸附, 使 $\mathrm{TiO}_{2}$ 薄膜内的电子传输加快, 电子注入效率 $\left(\eta_{\mathrm{in}}\right)$ 降低, $\mathrm{TiO}_{2}$ 导带边发生负移. 测试表明, 凝胶电池的开路电压 $\left(V_{\mathrm{oc}}\right)$ 、单色光转化效率 (IPCE) 和短路电流密度 $\left(J_{\mathrm{sc}}\right)$ 均低于液态电解质制备的染料敏化太阳电池(L-DSSC), 与上述分析结果符合, 且说明电解质 $/ \mathrm{TiO}_{2}$ 光阳极界面电 子复合起了主导作用. $108^{\circ} \mathrm{C}$ 的相转变温度保证了凝胶电解质的本征稳定性, 使得准固态电池在 $50^{\circ} \mathrm{C}$ 和一个太阳光照条件下连续 $1000 \mathrm{~h}$ 的 加速老化实验中表现出优良的光热稳定性. 